\title{
Partial drying of apple fruits to improve freeze/thaw quality during long term frozen storage.
}

\author{
Ben Haj Said, L. a; Bellagha, S. a $^{*}$ Allaf, K. ${ }^{\text {b }}$ \\ a Laboratory of valorization of natural heritage and Tunisian food through innovation, National \\ Institute of Agronomy of Tunisia, University of Carthage, 43, Avenue Charles Nicolle, 1082, Tunis \\ Mahrajene, Tunisia \\ ${ }^{\mathrm{b}}$ Laboratory of Engineering Science for Environment (LaSIE), UMR 7356 CNRS. Faculty of Science \\ and Technology, University of La Rochelle, avenue Michel Crepeau, 17042 La Rochelle cedex 01, \\ France.
}

*E-mail of the corresponding author: bellagha.sihemb@gmail.com

\begin{abstract}
Apple samples were submitted to partially drying prior to freezing. Then, quality assessments were achieved in order to evaluate the quality of these various frozen samples during frozen-storage. Significant positive effects of water content were observed on thaw exudate water and total color difference of dehydrofrozen/thawed apples. Total polyphenol content and total flavonoid content losses were important for samples without any dehydration pretreatment. They noticeably decreased when water content decreased during the whole period of storage. Thus, a partial removal of water prior to freezing is a relevant way to maintain the stability of fruit quality during long-term frozen-storage.
\end{abstract}

Keywords: Apple fruits; dehydrofreezing; frozen storage; color; polyphenol. 


\section{Introduction}

Dehydrofreezing is defined as a preservation method for fruits and vegetables characterized by their high water content. It is a process that involves a partial dehydration phase prior to freezing in order to diminish the amount of water and prevents the cell wall damage during freezing and thawing processes due to the increase of water volume during freezing. Previous investigations have demonstrated that dehydrofreezing reduces freezing time and improves freezing rates [1,2]. This combined process improves the textural firmness of frozen/thawed fruits and vegetables [3,4]. Dehydrofreezing reduces the thaw exudate water during thawing stage $[3,5,8,10]$. Several previous studies were interested on dehydrofreezing impacts on the global quality of fruits and vegetables through the assessment of different parameters such as color [6,7,10], ascorbic acid [3], and bioactive molecules [10]. Frozen fruits and vegetables undergo quality changes throughout the subsequent frozen storage. Moreover, physical changes during storage at negative temperatures may imply ice recrystallization, which results in deleterious textural and nutritional changes. It also would reverse the advantages of fast freezing. By inserting before freezing a pretreatment stage of partial dehydration, the quality loss of fruits and vegetables should be minimized not only during the freezing step but also during frozen storage. As far as we know, little information exists about the impact of the coupling of air drying and freezing processes on the nutritional quality and the bioactive composition of dehydrofrozen/thawed fruits and vegetables during long-period frozen storage. Thus, this study focused on studying the impact of the coupling of air drying and freezing, named dehydrofreezing process on the evolution versus frozen storage time at $-18{ }^{\circ} \mathrm{C}$ and initial water content of 1 / color, 2 / total polyphenol content, 3 / total flavonoid content, and 4 / the thaw exudate water during thawing of apple fruits.

\section{Materials and Methods}

\subsection{Process treatments}

\subsubsection{Partial drying}

1-cm Golden delicious apple disks with initial water content of about $7 \pm 0.1 \mathrm{~g} \mathrm{H}_{2} \mathrm{O} / \mathrm{g} \mathrm{db}$ (dry basis) were dried in an airflow dryer under constant conditions of airflow temperature $\left(45{ }^{\circ} \mathrm{C}\right)$, velocity $(2 \mathrm{~m} / \mathrm{s})$, and relative humidity $(12 \%)$. dehydration was stopped when selected water content levels were reached (2, 1 , and $\left.0.3 \mathrm{~g} \mathrm{H}_{2} \mathrm{O} / \mathrm{g} \mathrm{db}\right)$.

\subsubsection{Freezing}

Samples of fresh and partially airflow dried apple initially containing different water content levels (W); (7 (fresh), and 2, 1, and $0.3 \mathrm{~g} \mathrm{H}_{2} \mathrm{O} / \mathrm{g}$ db (for partially dehydrated 
samples)) were frozen in a freezer (Whirlpool Model AFG 363/G, Italy) with an air temperature of $-30^{\circ} \mathrm{C}$ at forced convection conditions.

\subsubsection{Frozen storage}

Frozen and dehydrofrozen apple samples were stored at $-18{ }^{\circ} \mathrm{C}$ for 18 months as Frozen Storage Time FST period. Samples were retrieved each month during the first three months of storage and each 3 months until the end of the storage period for quality assessments.

\subsubsection{Thawing}

Frozen and dehydrofrozen apple samples were thawed at $4{ }^{\circ} \mathrm{C}$ in a refrigerator (FAR Model RT 140, Romania) overnight just before starting the different analyzes.

\subsection{Quality assessments}

\subsubsection{Thaw exudate water}

Thaw exudate water (TEW) of frozen or dehydrofrozen apple samples was measured in triplicate for each treatment during the thawing phase [5].

\subsubsection{Color measurement}

For each sample, parameters L, a, and b were measured three times directly on the product using a colorimeter (Konica Minolta CR-410, Japan). Total color difference (TCD) between fresh and frozen and between dried and dehydrofrozen samples for each initial water content and storage time was calculated.

\subsubsection{Total polyphenol content}

Total polyphenol contents of fresh, dried, frozen, or dehydrofrozen/thawed apples were assayed during frozen storage [13].

\subsection{Statistical analysis}

Bifactorial analysis of variance and SNK test were carried out using the Statistical Package for the Social Sciences (SPSS) version 20.

\section{Materials and Methods}

\subsection{Thaw exudate water}

Table 1 shows the thaw exudate water (TEW) of apple samples just frozen, dehydrofrozen and during long-term frozen storage at $-18{ }^{\circ} \mathrm{C}$ for 18 months. 
Table 1. Effect of $-18^{\circ} \mathrm{C}$-storage on thaw exudate water during thawing of dehydrofrozen apple.

\begin{tabular}{|c|c|c|c|c|}
\hline \multirow{3}{*}{$\begin{array}{c}\text { FST } \\
\text { (months) }\end{array}$} & \multicolumn{4}{|c|}{ TEW (\%) } \\
\hline & \multicolumn{4}{|c|}{$\mathrm{W}\left(\mathrm{g} \mathrm{H}_{2} \mathrm{O} / \mathrm{g}\right.$ dry basis $\mathrm{db}$ ) } \\
\hline & 7 & 2 & 1 & 0.3 \\
\hline 0 & $14.64 \pm 0.92^{\mathrm{bA}}$ & $3.42 \pm 0.57^{\mathrm{aB}}$ & $0.38 \pm 0.13^{\mathrm{aC}}$ & $0.23 \pm 0.13^{\mathrm{aC}}$ \\
\hline 1 & $15.03 \pm 1.22^{\mathrm{bA}}$ & $3.47 \pm 2.21^{\mathrm{aB}}$ & $0.75 \pm 0.32^{\mathrm{aC}}$ & $0.25 \pm 0.19^{\mathrm{aC}}$ \\
\hline 2 & $16.70 \pm 2.05^{\mathrm{abA}}$ & $3.89 \pm 1.38^{\mathrm{aB}}$ & $0.63 \pm 0.10^{\mathrm{aC}}$ & $0.33 \pm 0.08^{\mathrm{aD}}$ \\
\hline 3 & $17.60 \pm 1.77^{\mathrm{abA}}$ & $2.88 \pm 1.81^{\mathrm{aB}}$ & $0.88 \pm 0.18^{\mathrm{aC}}$ & $0.23 \pm 0.05^{\mathrm{aD}}$ \\
\hline 6 & $17.18 \pm 1.48^{\mathrm{abA}}$ & $3.68 \pm 1.87^{\mathrm{aB}}$ & $0.75 \pm 0.18^{\mathrm{aC}}$ & $0.27 \pm 0.24^{\mathrm{aC}}$ \\
\hline 9 & $17.13 \pm 1.49^{\mathrm{abA}}$ & $3.81 \pm 1.26^{\mathrm{aB}}$ & $0.31 \pm 0.31^{\mathrm{aC}}$ & $0.21 \pm 0.16^{\mathrm{aC}}$ \\
\hline 12 & $20.18 \pm 0.63^{\mathrm{aA}}$ & $3.46 \pm 1.58^{\mathrm{aB}}$ & $0.64 \pm 0.20^{\mathrm{aC}}$ & $0.32 \pm 0.34^{\mathrm{aC}}$ \\
\hline 15 & $19.08 \pm 1.32^{\mathrm{abA}}$ & $3.53 \pm 1.78^{\mathrm{aB}}$ & $0.33 \pm 0.32^{\mathrm{aC}}$ & $0.22 \pm 0.13^{\mathrm{aC}}$ \\
\hline 18 & $19.77 \pm 1.05^{\mathrm{abA}}$ & $4.96 \pm 1.11^{\mathrm{aB}}$ & $0.83 \pm 0.26^{\mathrm{aC}}$ & $0.38 \pm 0.06^{\mathrm{aD}}$ \\
\hline
\end{tabular}

W: Initial water content $\mathrm{g} \mathrm{H}_{2} \mathrm{O} / \mathrm{g}$ dry basis $d b$ ), TEW: Thaw exudate water ( $\mathrm{g} / 100 \mathrm{~g}$ initial water); FST: Frozen storage time (months). Data are expressed as the mean \pm standard deviation. Different letters (A-D) within a same row differ significantly $(P<0.05)$. Different letters $(a-b)$ within a same column differ significantly $(P<0.05)$.

As previously indicated, since apple samples have initially before freezing different water contents, the thaw exudate water (TEW) was expressed as gram of water exudate/100 $\mathrm{g}$ initial water of concerned product before freezing. The impacts of initial water content (W) of apple samples and frozen storage time (SFT) on thaw exudate water (TEW) were investigated.

During thawing at a temperature of $4{ }^{\circ} \mathrm{C}$, TEW of fresh apple samples without previous dehydration (samples with $7 \mathrm{~g} \mathrm{H}_{2} \mathrm{O} / \mathrm{g}$ db as initial water content) was approximately of 15 g/100 g initial water. Fresh apple samples had significantly higher value of TEW than all partially air dried samples. This amount of TEW was important and significantly increased although slightly during the frozen storage time period of 18 months at $-18{ }^{\circ} \mathrm{C}$. According to Goncalves et al. [14], during frozen storage, recrystallization of ice crystals may cause more loss of cell turgor causing a leakage of fruit cell content and decrease of cell water holding capacity, resulting in increasing of thaw exudate water versus storage time.

Thaw exudate water was about $4 \mathrm{~g} / 100 \mathrm{~g}$ initial water for apple samples with initial water content of $2 \mathrm{~g} \mathrm{H}_{2} \mathrm{O} / \mathrm{g} \mathrm{db}$, and about $0.5 \mathrm{~g} / 100 \mathrm{~g}$ initial water for samples of 1 and $0.3 \mathrm{~g}$ $\mathrm{H}_{2} \mathrm{O} / \mathrm{g} \mathrm{db}$ initial water content. This low thaw exudate water level reveals high preservation of structural and textural quality issued from a better preservation of cell walls. This contributes to the slowing down of water loss from the internal cells [11].

From our point of view, the most important point, which is worth to be highlighted here is that, for previously dehydrated apple samples, TEW remained constant and negligible during the whole storage period. Partial removal of water before fruit freezing appeared as a 
relevant way to preserve the structural and maintain the textural properties of frozen/thawed fruits. This improves its stability during storage.

\subsection{Color}

Table 2 shows the total color difference (TCD) induced by freezing/dehydrofreezing and thawing of apple samples during storage at $-18{ }^{\circ} \mathrm{C}$ for 18 months and after thawing.

Table 2. Effect of $-18^{\circ} \mathrm{C}$-storage during 18 month-freezing on total color difference of dehydrofrozen apple.

\begin{tabular}{ccccc}
\hline \multirow{2}{*}{$\begin{array}{c}\text { FST } \\
\text { (months) }\end{array}$} & \multicolumn{4}{c}{ TCD (-) } \\
\cline { 2 - 5 } & 7 & \multicolumn{4}{c}{$\mathrm{W}\left(\mathrm{g} \mathrm{H} \mathrm{H}_{2} \mathrm{O} / \mathrm{g} \mathrm{db}\right)$} \\
\hline 0 & $33.56 \pm 5.94^{\mathrm{aA}}$ & $31.66 \pm 2.06^{\mathrm{aA}}$ & $21.88 \pm 7.71^{\mathrm{aA}}$ & $15.59 \pm 6.15^{\mathrm{aB}}$ \\
1 & $29.28 \pm 3.49^{\mathrm{aA}}$ & $30.47 \pm 6.91^{\mathrm{aA}}$ & $25.14 \pm 5.76^{\mathrm{aA}}$ & $15.61 \pm 4.53^{\mathrm{aB}}$ \\
2 & $28.20 \pm 5.19^{\mathrm{aA}}$ & $30.15 \pm 6.84^{\mathrm{aA}}$ & $25.72 \pm 2.86^{\mathrm{aA}}$ & $14.03 \pm 6.82^{\mathrm{aB}}$ \\
3 & $31.44 \pm 7.12^{\mathrm{aA}}$ & $34.62 \pm 5.98^{\mathrm{aA}}$ & $22.57 \pm 3.67^{\mathrm{aA}}$ & $10.91 \pm 3.96^{\mathrm{aB}}$ \\
6 & $32.70 \pm 1.93^{\mathrm{aA}}$ & $32.74 \pm 8.09^{\mathrm{aA}}$ & $26.51 \pm 7.45^{\mathrm{aA}}$ & $12.14 \pm 5.66^{\mathrm{aB}}$ \\
9 & $32.71 \pm 2.42^{\mathrm{aA}}$ & $32.48 \pm 5.63^{\mathrm{aA}}$ & $21.09 \pm 2.86^{\mathrm{aA}}$ & $15.10 \pm 7.52^{\mathrm{aB}}$ \\
12 & $27.74 \pm 6.21^{\mathrm{aA}}$ & $32.80 \pm 4.23^{\mathrm{aA}}$ & $25.20 \pm 7.54^{\mathrm{aA}}$ & $13.95 \pm 6.91^{\mathrm{aB}}$ \\
15 & $30.94 \pm 5.88^{\mathrm{aA}}$ & $30.66 \pm 5.19^{\mathrm{aA}}$ & $20.90 \pm 6.39^{\mathrm{aA}}$ & $11.50 \pm 5.79^{\mathrm{aB}}$ \\
18 & $29.34 \pm 5.47^{\mathrm{aA}}$ & $33.34 \pm 4.71^{\mathrm{aA}}$ & $20.81 \pm 5.19^{\mathrm{aA}}$ & $10.56 \pm 5.69^{\mathrm{aB}}$ \\
\hline
\end{tabular}

W: initial water content ( $\mathrm{g} \mathrm{H}_{2} \mathrm{O} / \mathrm{g} \mathrm{db}$ ), FST: Frozen storage time (months), TCD: total color difference (-). Data are expressed as the mean \pm standard deviation. For each color parameter, different letters $(A-B)$ within a same row differ significantly $(P<0.05)$. Different letters $(a-b)$ within a same column differ significantly $(P<0.05)$.

As it is shown in Table 2, the global effect of freezing and thawing processes on color decreased and became negligible for apple samples with low water content. Indeed, the total color difference (TCD) was 33.5 and 15.5 for samples with initial water contents of 7 and $0.3 \mathrm{~g} \mathrm{H}_{2} \mathrm{O} / \mathrm{g} \mathrm{db}$, respectively (Table 2). The freezing/thawing effect decrease is explained by the lower water activity of samples and consequently lower rate of enzymatic browning reactions [22]. The freezing impact decrease on fruit color is also attributed to the air-drying step, which caused the reduction of phenolase activity and enzymatic browning [23]. On the other hand, partial removal of water from fruit cells could protect product color due to lower structural damage as a result of freezing decreasing the enzymatic browning in damaged tissue [4].

In contrast, total color difference was almost constant during the whole storage period of 18 months at $-18^{\circ} \mathrm{C}$. According to Forni et al. [23], the air-drying step reduced the phenolase activity and thus increased color stability of dehydrofrozen/thawed apricot during storage. To conclude, the coupling of air drying and freezing processes induced lesser color changes at lower water content levels. These color losses are almost stable during the whole frozen 
storage period. Thus, the combination of these two conventional food unit operations is very useful for the color stability of frozen/thawed fruit during storage.

\subsection{Total polyphenol content}

The results of total polyphenol contents (TPC) in frozen and dehydrofrozen apples with different water contents during frozen storage at $-18{ }^{\circ} \mathrm{C}$ and after thawing are given in Table 3.

Table 3. Effect of $-18^{\circ} \mathrm{C}$-storage on total polyphenol content of dehydrofrozen apples.

\begin{tabular}{ccccc}
\hline \multirow{2}{*}{ FST (months) } & \multicolumn{4}{c}{ TPC $(\mathrm{g} \mathrm{AGE} / 100 \mathrm{~g} \mathrm{DW})$} \\
\cline { 2 - 5 } & \multicolumn{4}{c}{$\mathrm{W}(\mathrm{g} \mathrm{H} 2 \mathrm{O} / \mathrm{g} \mathrm{db})$} \\
\cline { 2 - 5 } 0 & $0.43 \pm 0.04^{\mathrm{aA}}$ & $0.19 \pm 0.03^{\mathrm{aC}}$ & $0.18 \pm 0.01^{\mathrm{aC}}$ & $0.29 \pm 0.01^{\mathrm{aB}}$ \\
1 & $0.44 \pm 0.01^{\mathrm{aA}}$ & $0.21 \pm 0.03^{\mathrm{aC}}$ & $0.19 \pm 0.01^{\mathrm{aC}}$ & $0.28 \pm 0.01^{\mathrm{aB}}$ \\
2 & $0.43 \pm 0.05^{\mathrm{aA}}$ & $0.19 \pm 0.01^{\mathrm{aC}}$ & $0.18 \pm 0.01^{\mathrm{aC}}$ & $0.27 \pm 0.01^{\mathrm{aB}}$ \\
3 & $0.40 \pm 0.03^{\mathrm{aA}}$ & $0.20 \pm 0.02^{\mathrm{aC}}$ & $0.18 \pm 0.01^{\mathrm{aC}}$ & $0.28 \pm 0.01^{\mathrm{aB}}$ \\
6 & $0.37 \pm 0.03^{\mathrm{aA}}$ & $0.21 \pm 0.02^{\mathrm{aC}}$ & $0.18 \pm 0.01^{\mathrm{aC}}$ & $0.28 \pm 0.01^{\mathrm{aB}}$ \\
9 & $0.38 \pm 0.02^{\mathrm{aA}}$ & $0.20 \pm 0.01^{\mathrm{aC}}$ & $0.19 \pm 0.01^{\mathrm{aC}}$ & $0.27 \pm 0.01^{\mathrm{aB}}$ \\
12 & $0.42 \pm 0.02^{\mathrm{aA}}$ & $0.21 \pm 0.01^{\mathrm{aC}}$ & $0.18 \pm 0.01^{\mathrm{aD}}$ & $0.28 \pm 0.01^{\mathrm{aB}}$ \\
15 & $0.40 \pm 0.05^{\mathrm{aA}}$ & $0.20 \pm 0.01^{\mathrm{aC}}$ & $0.19 \pm 0.02^{\mathrm{aC}}$ & $0.28 \pm 0.01^{\mathrm{aB}}$ \\
18 & $0.39 \pm 0.02^{\mathrm{aA}}$ & $0.20 \pm 0.01^{\mathrm{aC}}$ & $0.17 \pm 0.01^{\mathrm{aD}}$ & $0.26 \pm 0.01^{\mathrm{aB}}$ \\
\hline
\end{tabular}

W: Initial water content ( $\mathrm{g} \mathrm{H}_{2} \mathrm{O} / \mathrm{g} \mathrm{db}$ ); FST: Frozen storage time (months); TPC: total polyphenol content ( $g$ $A G E / 100 \mathrm{~g} \mathrm{DW})$.Data are expressed as the mean \pm standard deviation. Different letters (A-D) within a same row differ significantly $(P<0.05)$. Different letters $(a-d)$ within a same column differ significantly $(P<0.05)$.

Fresh Golden delicious apple samples present a total polyphenol content (TPC) of $0.62 \mathrm{~g}$ AGE/100 g db. Partial air drying results in significant reduction of TPC. TPC of partially dried apple samples were $0.26,0.22$, and $0.29 \mathrm{~g} \mathrm{AGE/100} \mathrm{g} \mathrm{db} \mathrm{for} \mathrm{water} \mathrm{contents} \mathrm{of} \mathrm{2,} \mathrm{1,}$ and $0.3 \mathrm{~g} \mathrm{H}_{2} \mathrm{O} / \mathrm{g} \mathrm{db}$, respectively. TPC losses as compared with fresh samples varied from 52 to 64\%. According to Korus [26], hot air drying caused phenolic compounds degradation and promoted polyphenols oxidation by the oxygen absorbed from the air of convective drying. Loss in polyphenol content is also ascribed to their use as reactants in the Maillard reaction.

Similarly, freezing caused significant reduction in TPC. TPC losses were important for apple samples without any pre-dehydration stage and decreased for partially dried apples before freezing. Indeed, TPC losses caused by freezing and thawing processes are about 30 , 25,17 , and $5 \%$ for samples with initial water contents of $7,2,1$, and $0.3 \mathrm{~g} \mathrm{H}_{2} \mathrm{O} / \mathrm{g} \mathrm{db}$, respectively. In fact, freezing results in cell de-compartmentalization allowing reactions between genuine enzyme activities and their corresponding substrates [27,28]. Therefore, phenolic compounds may already be degraded during thawing due to their interaction with 
oxidative enzyme activities such as polyphenoloxidases (PPO) which is more active at high water activity fruit samples [29,30].

As it is shown in Table 3, frozen storage time (FST) had insignificant effect on TPC for frozen and dehydrofrozen/thawed apple samples with different water contents. No data was found about the impact of coupling convective air drying and freezing on the polyphenol content of fruits and vegetables during their frozen storage.

\section{Conclusions}

The dehydrofreezing performed by coupling airflow dehydration, as pretreatment for partial removal of water from apple fruit cells, prior to freezing resulted in higher preservation quality in terms of reduced thaw exudate water reflecting better texture quality, color retention, and ameliorating the bioactive composition. This combined process guarantees the stabilization of frozen product quality accomplished during subsequent long term frozen storage.

To conclude the partial dehydration of fruits before freezing is a pertinent way to minimize the quality alteration caused by freezing and thawing processes and to obtain products with high quality stability during storage. However, the pretreatment used for water removal must be optimized to minimize the quality losses at this step.

\section{References}

[1] Ramallo LA and Mascheroni RH, Dehydrofreezing of pineapple. J Food Eng 99: 269275 (2010).

[2] Ben Haj Said L, Bellagha S and Allaf K, Dehydrofreezing of Apple Fruits: Freezing Profiles, Freezing Characteristics, and Texture Variation. Food Bioprocess Tech 9: 252-261 (2016).

[3] Ben Haj Said L, Bellagha S and Allaf K, Optimization of Instant Controlled Pressure Drop (DIC)-Assisted Dehydrofreezing Using Mechanical Texture Measurements Versus Initial Water Content of Apple. Food Bioprocess Tech 8: 1102-1112 (2015).

[4] Bolin HR and Huxsoll CC, Partial Drying of Cut Pears to Improve Freeze/Thaw Texture. J Food Sci 58: 357-360 (1993).

[5] Robbers M, Singh RP and Cunha LM, Osmotic-Convective Dehydrofreezing Process for Drying Kiwifruit. J Food Sci 62: 1039-1042 (1997).

[6] Sormani A, Maffi D, Bertolo G and Torreggiani D, Textural and structural changes of dehydrofreeze-thawed strawberry slices: Effects of different dehydration pretreatments / Cambiostexturales y estructurales de rodajas de fresadeshidratadas y descongeladas: Efectos de diferentespretratamientos de deshidratación. Food Sci Tech Inter 5: 479-485 (1999).

[7] Chiralt A, Martínez-Navarrete N, Martínez-Monzó J, Talens P, Moraga G, Ayala A, et al, Changes in mechanical properties throughout osmotic processes: Cryoprotectant effect. J Food Eng 49: 129-135 (2001). 
[8] Maestrelli A, Lo Scalzo R, Lupi D, Bertolo G and Torreggiani D, Partial removal of water before freezing: cultivar and pre-treatments as quality factors of frozen muskmelon (Cucumis melo, cv reticulatus Naud.). J Food Eng 49: 255-260 (2001).

[9] AOAC, Association of Official Analytical Chemists (15th edn).In 567 K. Helrich (Ed.). Arlington: Virginia 22201, USA (1990).

[10] Ben Haj Said L, Najjaa H, Neffati M and Bellagha S, Color, Phenolic and Antioxidant Characteristic Changes of Allium Roseum Leaves during Drying. J Food Qual 36: 403-410 (2013).

[11] Gonçalves EM, Abreu M, Branda o TRS and Silva CLM, Degradation kinetics of colour, vitamin $\mathrm{C}$ and drip loss in frozen broccoli (Brassica oleracea L. ssp. Italica) during storage at isothermal and non-isothermal conditions. Inter J Ref 34: 2136-2144 (2011).

[12] Van Buggenhout S, Lille M, Messagie I, VanLoey A, Autio K and Hendrick M, Impact of pretreatment and freezing conditions on the microstructure of frozen carrots: Quantification and relation to texture loss. Euro Food Res Tech 222: 543-553 (2006).

[13] Van Buggenhout S, Messagie I, Maes V, Duvetter T, Van Loey A and Hendrick M, Minimizing texture loss of frozen strawberries: effect of infusion with pectinmethylesterase and calcium combined with different freezing conditions and effect of subsequent storage/thawing conditions. Euro Food Res Tech 223: 395-404 (2006).

[14] Lowithun $\mathrm{N}$ and Charoenrein S, Influence of osmodehydrofreezing with different sugars on the quality of frozen rambutan. Inter J Food Sci Tech 44: 2183-2188 (2009).

[15] Dermesonlouoglou EK, Giannakourou MC and Taoukis P, Stability of dehydrofrozen tomatoes pretreated with alternative osmotic solutes. J Food Eng 78: 272-280 (2007).

[16] Dermesonlouoglou EK, Giannakourou MC and Taoukis P, Stability of dehydrofrozen tomatoes pretreated with alternative osmotic solutes. J Food Eng 78: 272-280 (2007).

[17] Dermesonlouoglou EK, Pourgouri S and Taoukis PS, Kinetic study of the effect of the osmotic dehydration pre-treatment to the shelf life of frozen cucumber. Innov Food Sci Emerg Tech 9: 542-549 (2008).

[18] Rincon A and Kerr WL, Influence of osmotic dehydration, ripeness and frozen storage on physicochemical properties of mango. J Food Process Preserv 34: 887-903 (2010).

[19] Tregunno NB and Goff HD, Osmodehydrofreezing of apples: structural and textural effects. Food Res Inter 29: 471-479 (1996).

[20] Forni E, Sormani A, Scalise S and Torreggiani D, The influence of sugar composition on the colour stability of osmodehydrofrozen intermediate moisture apricots. Food Res Inter 30: 87-94 (1997).

[21] Marani CM, Agnelli ME and Mascheroni RH, Osmo-frozen fruits: mass transfer and quality evaluation. J Food Eng 79: 1122-1130 (2007).

[22] Redmond GA, Gormley TR and Butler F, The effect of short- and long-term freezechilling on the quality of cooked green beans and carrots. Innov Food Sci Emerg Tech 5: 65-72 (2004).

[23] Korus A and Lisiewska Z, Effect of preliminary processing and method of preservation on the content of selected antioxidative compounds in kale (Brassica oleracea L. var. acephala) leaves. Food Chem 129: 149-154 (2011).

[24] Tomás-Barberán FA and Espín JC, Phenolic compounds and related enzymes as determinants of quality in fruits and vegetables. J Sci Food Agri 81: 853-876 (2001). 